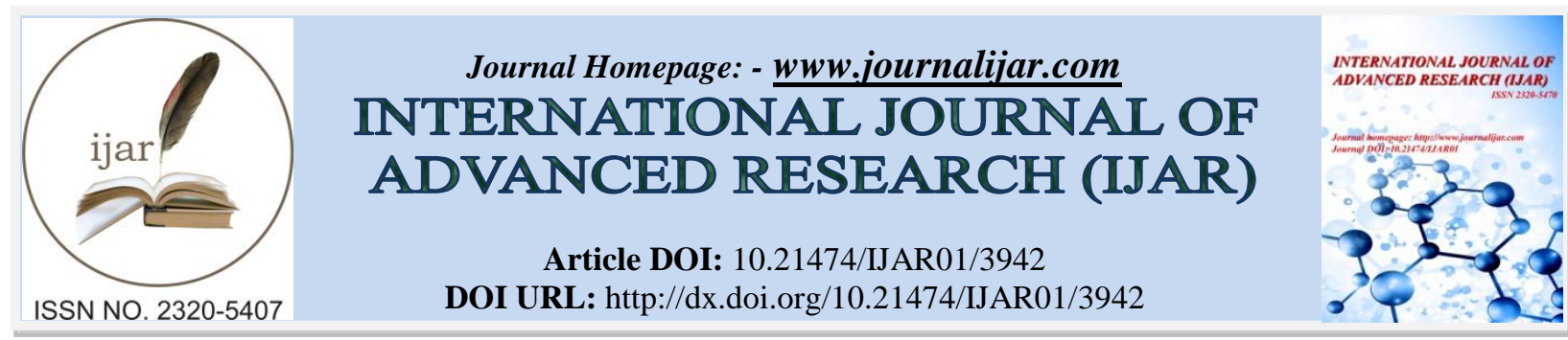

RESEARCH ARTICLE

\title{
THE BIOREFINING OF SAUDI ARABIAN WASTE DATE: AN ENVIRONMENTAL PROMISING ALTERNATIVE TO PETROCHEMISTRY.
}

Imen Ben Abdelmalek ${ }^{1,2}$, Abdulhameed Alzaiydi ${ }^{3}$ and Abir Ben Bacha ${ }^{4}$.

1. Department of Biology, Faculty of Science and Arts at Buraidah, Qassim University, Saudi Arabia.

2. Laboratory of Biomass Valorisation and Protein Production in Eukaryotes, Centre of Biotechnology of Sfax, University of Sfax, P.O. Box 1177, 3038, Sfax, Tunisia.

3. Departement of mathematic, Faculty of Science at Buraidah, Qassim University, Saudi Arabia

4. Department of Biochemistry, Science College, King Saud University, P.O. Box 22452, Riyadh 11495, Saudi Arabia

\section{Manuscript Info}

Manuscript History

Received: 18 February 2017

Final Accepted: 14 March 2017

Published: April 2017

Key words:-

Bioethanol, green chemistry,

lignocellulose, date waste materials, Process optimization, Fermentation process

\begin{abstract}
Saudi Arabia area is one of the world's major producers of dates and thus date flesh, pit, and skin are commonly available agricultural waste to be used as lignocellulosic substrate. Present study focuses on exploitation of date waste as a source for bioethanol production from the fermentable sugars released due to different chemical and biological pretreatments.

Two fungal strains Aspergillus awamori and Aspergillus niger reported to be producing cellulolytic enzymes were used under co-culture fermentation on waste date to degrade pectin-rich wastes fruit and facilitate maximum release of reducing sugars. The hydrolysate obtained after alkali and microbial treatments was then fermented by Saccharomyces cerevisiae KD2 to produce bioethanol. Fermentation of cellulosic hydrolysate (15\%) gave maximum ethanol yield around $95 \%$ after $72 \mathrm{~h}$ at $35^{\circ} \mathrm{C}$ and $\mathrm{pH} 5$. It was observed that pretreated waste date can be economically utilized as a cheaper substrate for bioethanol production considered as a viable alternative fuel to solve both energy and environmental crises.
\end{abstract}

Copy Right, IJAR, 2017,. All rights reserved.

\section{Introduction:-}

Face to a new environmental concern (global warming, need to control and to reduce of toxic gas emissions, etc.) and to the price increase of fossil resources, Researches \& Development activities are moving both all over the world in industry research institutes, to the development of new technologies based on the alternative use of renewable raw materials. In fact, it is generally accepted in the worldwide scale a rational and sustainable use of biomass that can potentially replace some fossil fuels especially in the energy sector at the level of other sectors such as the chemical and materials industry ([1], [2], [3], [4], [5]). Hence was born the concept of biorefinery (or plant refinery) that valorizes all the plant to produce higher added value products ([6]). So, the biorefinery can be defined as the process of sustainable transforming of the biomass into a bio-based products range (including food, chemicals and biomaterials) and bioenergy (biofuels, electricity, heat) marketable.

In a biorefinery, a wide range of processes and technologies for sustainable transformation are used. These allow splitting one or more plant resources (wood, straw, stones, corn, wheat, soybeans, etc.) into their individual 
components (carbohydrates, lignin, protein, triglycerides, etc.) and converting them into high added value products. Several types of biorefinery can be defined depending on the type of plant resources used. These are the green biorefinery, cereal biorefineries, oil biorefineries and lignocellulosic biorefineries ([7], [8], [2], [3]).

1. Green biorefineries ([9]) are industries that work as seasonal cycles for the processing of wet biomass. They typically use the grass, alfalfa, clover, immature grains and perishable resources requiring prompt treatment, such as potatoes or sugar beets and mainly produce biofuels.

2. Polysaccharide biorefineries ([2], [3], [10]) are industries that transform dry cereal (mainly corn, wheat and rice) as seeds to produce mainly bioethanol.

3. The oil biorefineries ([11], [12]) are industries that transform seed oil types (colza, sunflower, soybean, etc.) To produce mainly biodiesel, basic molecules for the oleochemical industry and compounds to the human and animal food.

4. Lignocellulosic biorefineries ([13], [14], [15], [16]) are industries processing resources from wood and any lignocellulosic biomass (straw, bamboo, Miscanthus, etc. ) to produce mainly biofuels, lignin, biopolymers ([17]) and energy.

One of the known agriculture waste in Gulf Cooperation Council (GCC) countries, and particularly in Saudi Arabia area that is considered as one of the world's major producer of dates, we mentioned the palm date waste. This date waste commonly named "date by-products" consist of three main parts: date flesh, date pit, and skin mainly composed of cellulose, hemicellulose, lignin, glucose, fructose, sucrose and insoluble proteins. However, it is an excellent and very attractive resource useable in all types of biorefineries. In fact, date trees produce large quantities of agricultural waste and according to one estimate; each date tree produces about $20 \mathrm{~kg}$ of dry leaves yearly. Other wastes such as date pits represent an average of $10 \%$ of the date fruits ([18], [19]). They were burned in farms causing a serious threat to the environment. So, an environmentally friendly solution and alternative economic use for this agricultural residue is needed.

The degradation of raw cellulosic material is gaining increasing research attention due to its worldwide availability and the immense potential for its transformation into sugars, alternative fuels and chemical feed stocks and in particular for the bioethanol production ([20]). Overall the steps involved in fuel ethanol production from lignocellulosic biomass consists of feedstock preparation, pretreatment, fractionation, enzymatic hydrolysis (saccharification), fermentation, product recovery and waste treatment ([21]).

As part of our study of cost effective means of producing fuels from biomass, we report a process for ethanol producing from lignocellulosics prehydrolysed by alkali followed by saccharification carried by co-cultivation of $A$. awamori and $A$. niger and fermentation of the released fermentable sugars to bioethanol, using a yeast strain Saccharomyces cerevisiae KD2 in five liter capacity bioreactor designed for ethanol production. certain fermentation parameters such as substrate concentration, optimum $\mathrm{pH}$, temperature, time, playing important roles in obtaining good ethanol yield had been optimized.

\section{Material and Methods:-}

In our project, we will use date waste in the bioconversion processes aimed at fuel ethanol production, with emphasis on process integration. In particular, the concept that each individual unit operation has to be developed and optimized in relation to the preceding and subsequent process steps will be discussed.

\section{Raw materials and Microorganisms culture conditions:-}

Receive date wastes from Qassim, Kingdom of Saudi Arabia, will be in the first time washed thoroughly with water to remove all foreign materials. All wastes were than thermo chemically pretreated using dilute sulphuric acid and sodium hydroxide. For optimization study the parameters varied were: biomass concentration (1-10\%, w/v), sulphuric acid/sodium hydroxide concentration (0.1-1 M) and incubation time (5-40 min). After each type of pretreatment biomass was washed with distilled water and then dried overnight at $70{ }^{\circ} \mathrm{C}$. After that dried biomass was subsequently used for enzymatic hydrolysis experiments ([22]).

Industrial production of commercially important enzymes such as Carboxymethylcellulase (CMCase), pectinase (PGase) and xylanase (Xylase) etc., largely depend on cheap enzyme production media formulated with simple and cheap substrates for the economic production of enzymes. Date by-products and wastes were also experimented as complementary substrates in the enzyme production medium for few industrial enzymes by investigators. From the literature available it was inferred that date fruits could be successfully used in the production medium as substrate 
for the production of Carboxymethylcellulase (CMCase), pectinase (PGase) and xylanase (Xylanase) by $A$. awamori and A. niger ([23]).

So, treated substrates were utilized for cellulolytic enzyme production by a cocultivation of A. awamori and A. niger. In the first step fungus were were maintained on potato dextrose agar (PDA) medium and were revived once in a month on PDA slants at $30 \pm 2{ }^{\circ} \mathrm{C}$ for 7 days and were stored at $4{ }^{\circ} \mathrm{C}$. For enzyme production, the fungus were grown in a Mandels minimal liquid medium ([24]) containing 2\% of waste dates. The minimal medium contained equally $\mathrm{KCl}, 1 \mathrm{~g} / \mathrm{L} ; \mathrm{MgSO}_{4}, 0.5 \mathrm{~g} / \mathrm{L} ; \mathrm{KH}_{2} \mathrm{PO}_{4}, 1 \mathrm{~g} / \mathrm{L} ; \mathrm{NaNO}_{3}, 1.4 \mathrm{~g} / \mathrm{L} ;\left(\mathrm{NH}_{4}\right) 2 \mathrm{SO}_{4}, 4 \mathrm{~g} / \mathrm{L}$; yeast extract, 2 g/L and 1 $\mathrm{mL} / \mathrm{L}$ trace elements solution was used. The trace element comprising COCl, $2 \mathrm{~g} / \mathrm{L} ; \mathrm{MnSO}_{4}, \mathrm{H}_{2} \mathrm{O}, 1.6 \mathrm{~g} / \mathrm{L} ; \mathrm{ZnSO}_{4}$, $\mathrm{H}_{2} \mathrm{O}, 1.4 \mathrm{~g} / \mathrm{L} ; \mathrm{FeSO}_{4}, 7 \mathrm{H}_{2} \mathrm{O}, 5 \mathrm{~g} / \mathrm{L}$. The $\mathrm{pH}$ was adjusted to 5.5 with $\mathrm{HCl}$ solution before autoclaving. The cultures were inoculated with mycelia disks cut from 3-day-old colonies. The incubation was carried out on shaker (G24 Environmental incubator shaker, New Brunswick Scientific, Edison, NJ) at $25{ }^{\circ} \mathrm{C}$ and 150 rpm for 9 days. The mycelia were then removed by filtration on GF/D paper and centrifugation 9,000 g during 30 min at $4^{\circ} \mathrm{C}$. Crude enzyme extract obtained was analyzed for various enzyme activities. Cellulolytic enzymes obtained are used for carrying out saccharification and saccharified hydrolysate utilized for ethanol production.

Yeast strain $S$. cerevisiae KD2 was maintained on malt extract-glucose-yeast extract-peptone (MGYP) medium (g\%): malt extract, $0.3 \mathrm{~g}$; glucose, $1.0 \mathrm{~g}$; yeast extract, $0.3 \mathrm{~g}$; peptone, $0.5 \mathrm{~g}$; agar, $2.0 \mathrm{~g}$; Adjust pH to 6.4-6.8. The biomass was obtained by cultivating the yeast cells in MGYP broth medium and $1 \times 10^{7}$ cells were used for inoculation into fermentation media. During the fermentation process biomass obtained was deflocculated by washing 2-3 times with sterile normal saline $(0.9 \% \mathrm{NaCl})$, prior to $\mathrm{OD}_{600}$ measurements and correlated to the cell dry weight $(\mathrm{CDW})$ by a standard curve. CDW was determined by filtering $10 \mathrm{~mL}$ yeast culture through a preweighed $0.45 \mu \mathrm{m}$ filter and washing with $20 \mathrm{~mL}$ water. The filter was dried overnight at $104{ }^{\circ} \mathrm{C}$, cooled in a desiccators and weighed to constant weight.

\section{Alcoholic fermentation:-}

The alcoholic fermentation is to convert fermentable sugars by anaerobic yeast into alcohol and carbon dioxide with the release of calories in anaerobically condition according to the following reaction:

$$
\text { Sugar }+ \text { Yeast }======>\text { Ethanol }+\mathrm{CO}_{2}+\text { Energy }
$$

The criteria for an ideal ethanol-producing microorganism are to have (a) higher growth and fermentation rate, (b) high ethanol yield, (c) high ethanol and glucose tolerance, (d) osmotolerance, (e) low optimum fermentation pH, (f) high optimum temperature, $(\mathrm{g})$ general hardiness under physiological stress, and $(\mathrm{h})$ tolerance to potential inhibitors present in the substrate ([25], [26]).

S. cerevisiae KD2 is by far the most well-known and most widely used yeast in industry and research for ethanol fermentation. These strains tolerate in generally high concentrations of ethanol but are sensitive to glucose effect. It should also be noted that these strains have the particularity to settle in the culture medium at the end of fermentation. This flocculation is a favorable factor for the separation of yeast ([27]).

\section{Effect of temperature and initial $\mathrm{pH}$ on the bioethanol production:-}

Temperature plays a major role in the production of ethanol, since the rate of alcoholic fermentation increases with the increase in temperature. The fermentation process is always accompanied with evolution of heat that raises the temperature of the fermenter. As a result it becomes necessary to cool the large fermenters in the distilleries. To optimize the fermentation temperature, fermentation of $S$. cerevisiae $\mathrm{KD} 2$ was carried out at $15,20,25,30$ and $35^{\circ} \mathrm{C}$. The periodic samples were analyzed for reducing sugars and ethanol content ([28]).

The effect of $\mathrm{pH}$ on bioethanol production was tested by adjusting the production medium $\mathrm{pH}$ to 5.0, 6.0, 7.0 and 8.0 before autoclaving. Low $\mathrm{pH}$ inhibits the yeast multiplication.

\section{Effect of sugar concentration:-}

To study the effect of sugar concentration on ethanol production by $S$. cerevisiae KD2, the production media was prepared to sugar concentration of $5,10,15,20,25$, and 30 percent with distilled water and filtered through ordinary filter paper to remove suspended particles ([28]). Fermentation was carried out in 250 ml conical flasks. A twenty four hour old inoculum of yeast was added at the rate of 6 percent to the medium. Samples were withdrawn after every 12-hour interval for the growth kinetics study at $600 \mathrm{~nm}$ and to estimated residual sugars ([29]) as well as ethanol content in the media ([30]). GC method for estimating the percentage of ethanol was employed. The initial 
sugar concentration that was efficiently utilized by the yeast for ethanol production was selected and maintained in fermentation media for further use.

\section{Analytical techniques:-}

Chemical composition of dates waste:-

The cellulose, hemicellulose and lignin were estimated by acid detergent method developed by Goering and Van ([31]).

\section{Reducing sugar Estimation:-}

Total reducing sugars were determined by the method of Miller ([29]). The reaction mixture contained $0.5 \mathrm{ml}$ of crude extract and $0.5 \mathrm{ml}$ dinitrosalicylic acid reagent. The tubes were heated in a boiling water bath for 10 min. After cooling to room temperature, the absorbance was measured at $560 \mathrm{~nm}$. Glucose served as the calibration standard for total reducing sugar determination.

\section{Cellulolytic enzyme estimation:-}

Carboxymethylcellulase (CMCase), pectinase (PGase) and xylanase (Xylase) activities were assayed by determining the liberated reducing end products using glucose, galacturonic acid and xylose as standards, respectively ([32]). Substrates used were CM-cellulose, polygalacturonic acid and birchwood xylan for CMCase, PGase and Xylanase, respectively. The reaction mixture $(0.5 \mathrm{ml})$ contained $1 \%$ substrate, $0.05 \mathrm{M}$ sodium acetate buffer $\mathrm{pH} 5.5 \mathrm{and} 0.1 \mathrm{ml}$ crude extract. Assays were carried out at $50{ }^{\circ} \mathrm{C}$ for $30 \mathrm{mn}$. Then $0.5 \mathrm{ml}$ dinitrosalicylic acid reagent was added to each tube. Then the reaction mixture was mixed well, and heated in a boiling water bath for 10 min. After cooling to room temperature, the absorbance was measured at $560 \mathrm{~nm}$. One unit of enzyme activity is defined as the amount of enzyme which liberated one $\mu \mathrm{mol}$ of reducing sugar per min under standard assay conditions. All the experimental work was run in triplicates.

\section{Ethanol determination:-}

Ethanol was estimated from samples by dichromate oxidation and thiosulphate titration ([33]). Purity of ethanol produced was analyzed by gas chromatography (GC) method. A computer related Nucon series gas chromatograph equipped with flame ionization detector (FID) was employed for the separation and quantification of ethanol. A stainless steel column $(5 \mathrm{~m} \times 2 \mathrm{~mm})$ was fitted into the instrument to provide on column injection. The column packing was Porapak Q. The detector and injector temperature was maintained at $200^{\circ} \mathrm{C}$. The gas chromatograph was connected to an integrator and computer system to determine area of ethanol and internal standard peak ([28]).

\section{Protein determination:-}

Protein concentration was determined according to the dye binding method of Bradford ([34]) with bovine serum albumin as standard.

\section{Results and Discussion:-}

Lignocellulose consists of three main components: cellulose, hemicellulose and lignin, the first two being composed of chains of sugar molecules. These chains can be hydrolysed to produce monomeric sugars, some of which can be fermented using ordinary baker's yeast. To attain economical feasibility a high ethanol yield is a necessity. Therefore, although the cost of lignocellulosic biomass is far lower than that of sugar and starch crops, the cost of obtaining sugars from such materials for fermentation into bioethanol has historically been far too high to attract industrial interest. For this reason, it is crucial to solve the problems involved in the conversion of date waste lignocellulose to sugar and further to ethanol ([35], [36]).

In the first step of our study we have analyzed the biochemical composition of raw and pretreated waste date that will be used as substrate for enzyme production. Result mentioned in table 1 showed that after pretreatment lignin and hemicelluloses content decreased considerably but there was no significant effect on cellulose content. This observation was might be due to selective degradation of lignin and hemicelluloses after alkaline pretreatment. Similar type of observation was reported previously in case of sodium hydroxide treated corn stover, Wheat straw and cotton stalk ([22], [37]). For enhanced enzymatic hydrolysis, there needs low lignin content and high cellulose content. The present result showed effectiveness of dilute alkaline pretreatment for efficient hydrolysis of the waste date lignocellulosic biomass ([22]). 
Fermentation using $2 \%$ alkali pre-treated date waste as unique source of carbon was tested for the production of fermentable sugar by the co-cultivation of A. awamori and A. niger. In fact, these funguses can degrade waste date macromolecules by using a battery of hydrolytic enzymes or oxidative process ([38]). Degradation of the lignocellulosic materials to monomeric fermentable sugars through the concerted action of cellulolytic enzymes is of great importance because sugars can serve as the raw material for a number of biotechnological production processes such as bioethanol production ([39]).

Production of biocatalyst is closely related to maximum growth of the organism on the substrates ([40], [41]) and therefore there is an association between incubation time and enzyme production.

The kinetic of CMCase, PGase and Xylanase production by fungus, as well as the cultivation time to reach the corresponding peak activities using waste date are presented in Figure 1. In fact during the early growth phase of 1 to 3 days, the cellulolytic enzyme production proceeded at a slower rate after which it increased sharply reaching a high value of Xylanase (100U/g), CMCase $(320 \mathrm{U} / \mathrm{g})$ and PGase $(270 \mathrm{U} / \mathrm{g})$ recorded respectively at 4,6 and 8 days of incubation. Further incubation resulted in a quick decline in the enzyme productions. This decline might be due to cessation of enzyme synthesis together with autolysis.

The highest concentration of fermentable sugar with a total of $62 \mathrm{mg} / \mathrm{g}$ substrate was obtained on day 5 of fermentation (figure 2). This amount of reducing sugar is higher that found by Hong et al., which stated that fermentable sugar in the concentration of $57 \mathrm{mg} / \mathrm{g}$ was obtained on tapioca meal after 7 days of A. niger USM AI1 fermentation ([42]). Maximum value of fermentable sugar obtained in this study was more important than previous finding which reported by Saravanan et al. and Teoh et al. ([43], [44]). it only shows $20.02 \mathrm{mg}$ fermentable sugars/g substrate and $9.88 \mathrm{mg} \mathrm{g}^{-1}$ substrate respectively. The used of lignocellulolytic materials for the production of fermentable sugars has been reported widely from fungal as well as Aspergillus genus have previously been reported ([45]). Sugarcane, sugar beet, sweet sorghum, and some fruits are known to be a good sources of sugar-rich juices and used as feedstocks in ethanol production ([46]).

As shown in Figure 2 the amount of reducing sugar decreased drastically until 8 days of fermentation, probably due to the consumption of fermentable sugar by A. awamori and A. niger during fungus growth. This is evident from Figure 2 in which the reducing sugar concentration was seen to be decreasing when fungus growth increased as indicated by the increasing total protein content during the course of fermentation, the same result was found with the cultivation of Pycnoporus sanguineus on alkali-pretreated sugarcane Bagasse ([47]).

To increase the initial concentration of fermentable sugar in the crude extract obtained from alkali and cellulolytic enzyme treated waste date, it was further concentrated using rotary evaporator (Buchi, Switzerland). The concentrated hydrolysate (45 g \% sugar) was used with different concentration for ethanol production in lab-scale bioreactor ( $5 \mathrm{~L}$ capacity glass bioreactor) with working volume $3.5 \mathrm{~L}$. It was inoculated with $5 \%$ inoculum of yeast cells. The enzymatic hydrolysate was further supplemented with $(\mathrm{g} / \mathrm{L})$ : $\left(\mathrm{NH}_{4}\right)_{2} \mathrm{SO}_{4} 0.5 ; \mathrm{KH}_{2} \mathrm{PO}_{4} 0.5$; yeast extract 2.5 , without aeration and agitation for $72 \mathrm{~h}$. The fermentation of $S$. cerevisiae KD2 strain was carried out at varying temperature, $\mathrm{pH}$, reducing sugar concentration, The samples were collected at different intervals and centrifuged at $10,000 \mathrm{rpm}$ at $4{ }^{\circ} \mathrm{C}$ for $10 \mathrm{~min}$ and the cell free supernatant was used for ethanol analysis.

S. cerevisiae is the most attractive choice in fermentation due to its greater efficiency in sugar conversion to alcohol and capability of producing flocs during growth, making it easier to settle or suspend on need ([48]), and high tolerance to ethanol ([49]).

Initial sugar concentration is an important influencing parameter as it has the direct effect on fermentation rate and microbial cells. Generally, fermentation rate will be increased with the increase in sugar concentration up to a certain level. But excessively high sugar concentration will exceed the uptake capacity of the microbial cells leading to a steady rate of fermentation ([50]).

as shown in Figure 3 we conclude that the growth of $S$. cerevisiae increase with an gradually increasing of sugar concentrations to reach an maximum optical density on $15 \%$ sugar concentration in fermentation medium. However on increasing the sugar concentration beyond this reducing sugar concentration, the growth was inhibited as shown by the optical density measured. The highest yield of ethanol $(92 \%)$ was obtained with initial reducing sugar concentration $15 \%$. The increase or decrease of initial reducing sugar concentration from $15 \% \mathrm{w} / \mathrm{v}$ results a decrease 
of ethanol yield. Figure 3 shows that ethanol yield increases sharply when initial reducing sugar concentration increase from 5 to $15 \% \mathrm{w} / \mathrm{v}$ but declines slightly to $79 \%$ with $20 \%$ reducing sugar concentration and ethanol yield remains unchanged during fermentation with $20-30 \%$ reducing sugar concentration, The same observation was found with Saccharomyces cerevisiae IFST-072011 cultivated on molasses ([51]). .

The harmful effect of high sugar concentration on ethanol production was well studied in Kluyveromyces marxianus and a sucrose concentration more than $23 \%$ in molasses was found to affect ethanol production ([52]). Therefore, in the present study growth and fermentation were carried out with sugar concentrations up to $15 \%$.

With the initial sugar concentrations, Temperature and $\mathrm{pH}$ are greatly essential parameters that influence the specific rate of yeast growth and ethanol production. To know the optimum temperature for ethanol fermentation, the solutions were kept at $25,30,35$ and $40^{\circ} \mathrm{C}$ with $15 \%$ initial sugar concentration. Two parameters were simultaneously studied, the growth of $S$. cerevisiae KD2 strain and the ethanol yield. Samples were withdrawn every 12 hours and the fermentation was carried out for 72 hours. Figure 4 showed the ethanol yield produced at different temperature. Based on the result obtain, a low ethanol concentration $(72 \%$ and $89 \%$ was observed respectively at 25 and $30^{\circ} \mathrm{C}$ in $72 \mathrm{~h}$. At $35^{\circ} \mathrm{C}$ ethanol yield was maximum and turned out to be $95 \%$. However increasing the temperature beyond $35^{\circ} \mathrm{C}$ the growth as well as alcohol yield decreased. This decrease was pronounced at $40^{\circ} \mathrm{C}$. The yield of ethanol at various temperatures indicates that the fermentation temperature $35^{\circ} \mathrm{C}$ is the optimum temperature for production of ethanol by the strain, $S$. cerevisiae strain KD2, Temperature that is too high kills yeast, and low temperature slows down yeast activity. This finding is in agreeable with last studies about temperature effect on ethanol production ([53][54][55]). This studies result also denied the study of Yah et al., (2010) ([56]), who found optimum temperature of ethanol production to be $25^{\circ} \mathrm{C}$.

Initial sugar concentration of $15 \%$ and optimum temperature of $35^{\circ} \mathrm{C}$ was selected for further studies and subjected to $\mathrm{pH}$ treatments $4,5,6,7$ and 8. Figure 5 showed the effect of different initial $\mathrm{pH}$ on ethanol production by $S$. cerevisiae KD2 after $72 \mathrm{~h}$ of incubation. These results clearly showed that the highest concentration of ethanol (96\%) by this strain was produced after $72 \mathrm{~h}$ when the initial $\mathrm{pH}$ was 5 . Followed by $\mathrm{pH} 4$ which is $86 \%$, then $\mathrm{pH} 6$ at $75 \%$ and $\mathrm{pH} 7$ at $60 \%$. The lowest ethanol yield was observed at pH 8. These results are agreement with thus of Yadav et al (1997) ([57]) that found an increase in alcohol concentration, productivity as well as efficiency with an increase in $\mathrm{pH}$ from 4.0-5.0 and found that the optimum $\mathrm{pH}$ range for S. cerevisiae strain HAU-1 to be between $\mathrm{pH} 4.5-5.0$ ([58]). Based on fermentation efficiency the $\mathrm{pH} 5$ was selected for further experimentation.

\section{Conclusion:-}

Date is a major fruit in Saudi Arabia and which results in accumulation of cellulosic biomass waste in agricultural practices, which could serve as novel material for the production of biethanol. Fermentation of waste date to bioethanol is very encouraging and an attractive alternative technology for the production of biofuels using cellulolytic fungi and yeast.

We used two cellulase producing fungal strains A. awamori and A. niger under co-culture fermentation on alklipretreated waste date to release fermentable sugar, which was later used as a substrate for ethanol production by yeast strain $\mathrm{S}$. cerevisiae KD2. The submerged fermentation of the yeast under optimized conditions $\mathrm{pH}$, sugar concentration $15 \%$ and temperature $35^{\circ} \mathrm{C}$ revealed an increase in ethanol production with good fermentation efficiency. This research may be meaningful both in the conversion and utilization of renewable biomass, and in the reduction of environmental pollution.

\section{Acknowledgements:-}

We wish to express our sincere gratitude to Qassim University represented by the Deanship of Scientific Research and SABIC for the materials and financial support provided in the course of this research. 
Table 1: Biochemical composition of lignocellulosic biomass of the waste date.

\begin{tabular}{|c|c|c|c|}
\hline Biomass type (\%) & Cellulose & Hemicellulose & Lignin \\
\hline Lignocellulosic biomass (raw waste date) & 43.00 & 31.50 & 25.60 \\
\hline Lignocellulosic biomass (alkali pretreated waste date) & 50.00 & 14.00 & 11.50 \\
\hline
\end{tabular}

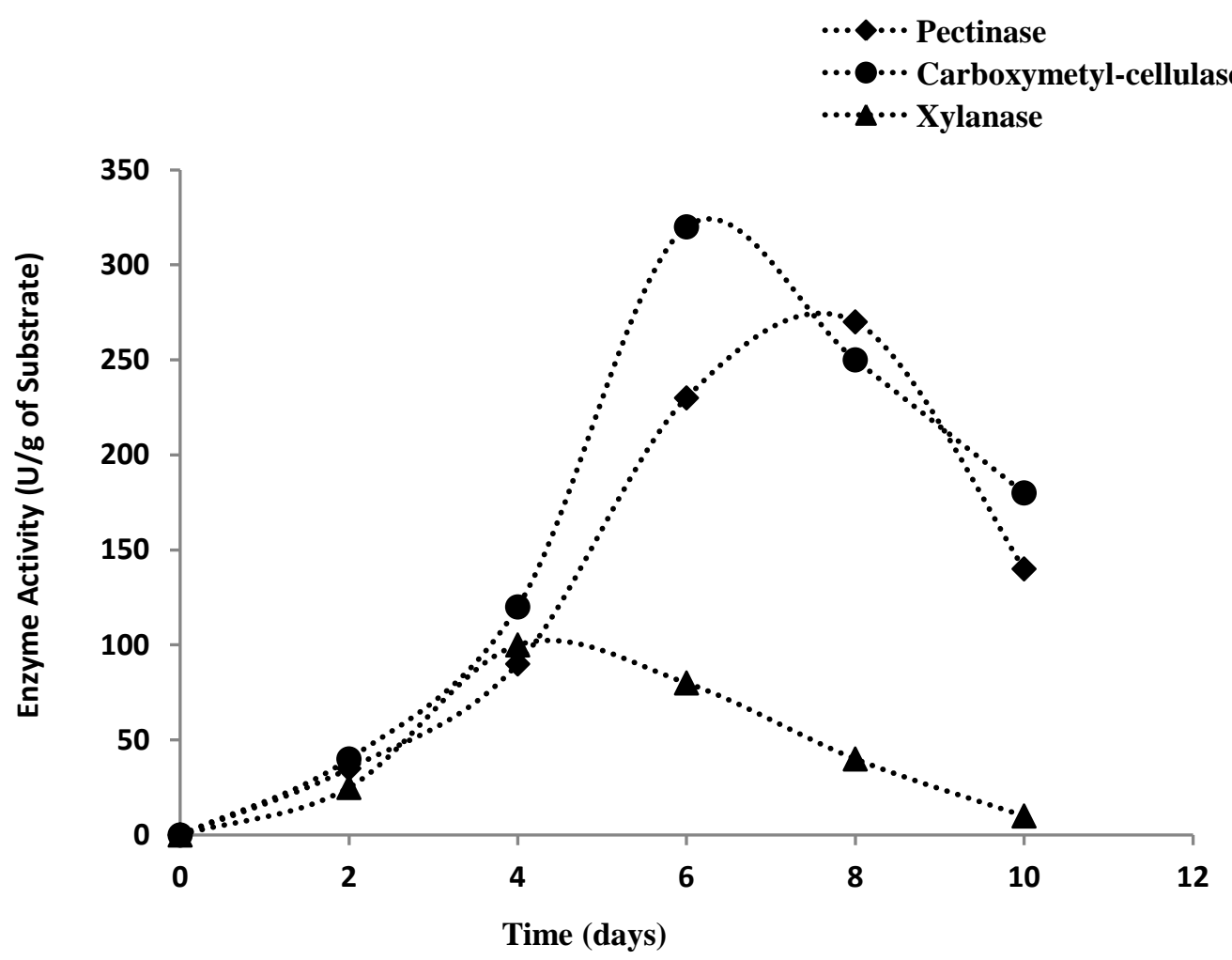

Figure 1:- Cellulolytic enzyme production profile during submerged fermentation of waste date by the cocultivation of A. awamori and A. niger. 


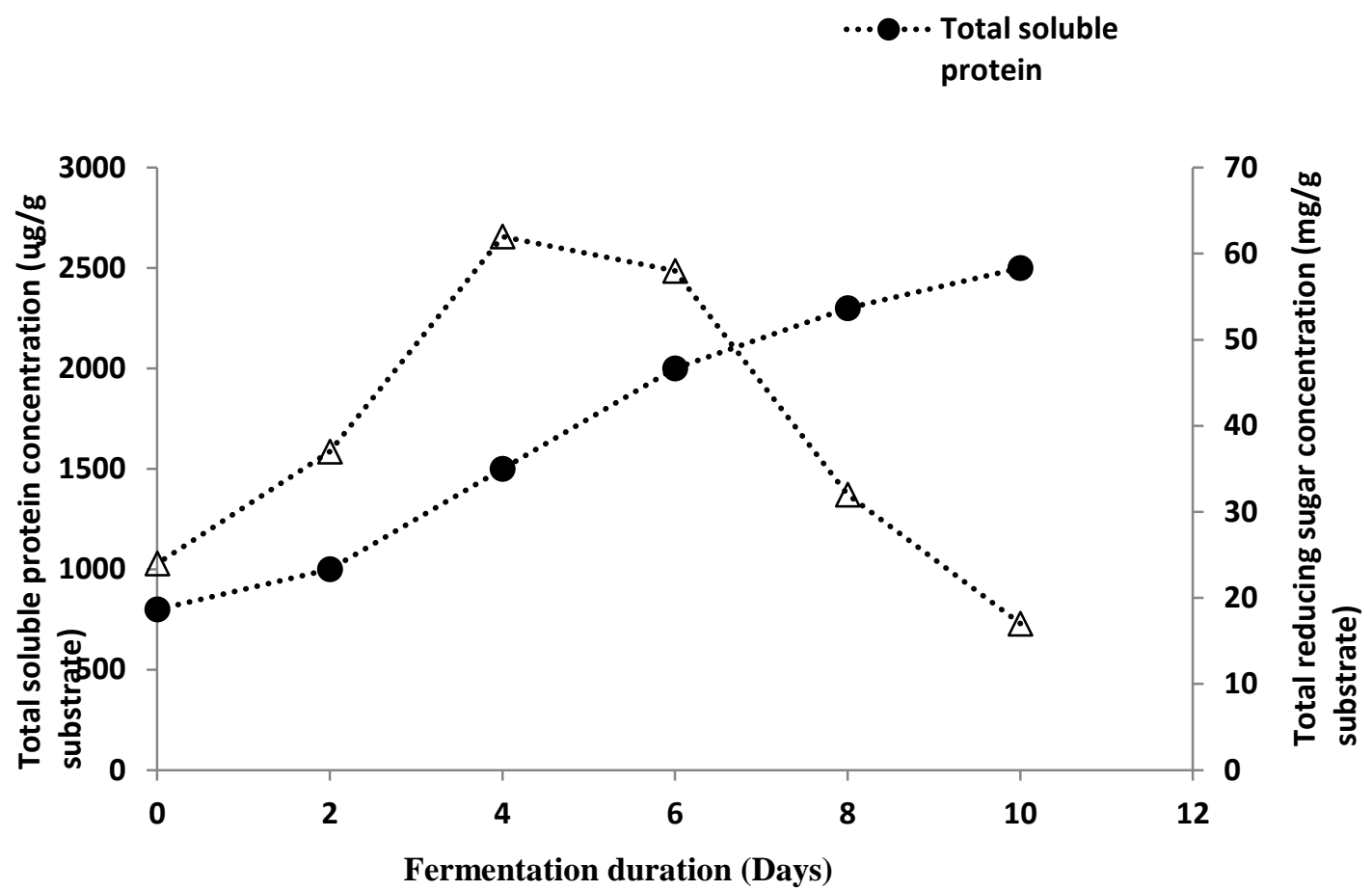

Figure 2:- Time profile of reducing sugar concentration and total soluble protein content during submerged fermentation of waste date by the co-cultivation of A. awamori and A. niger.

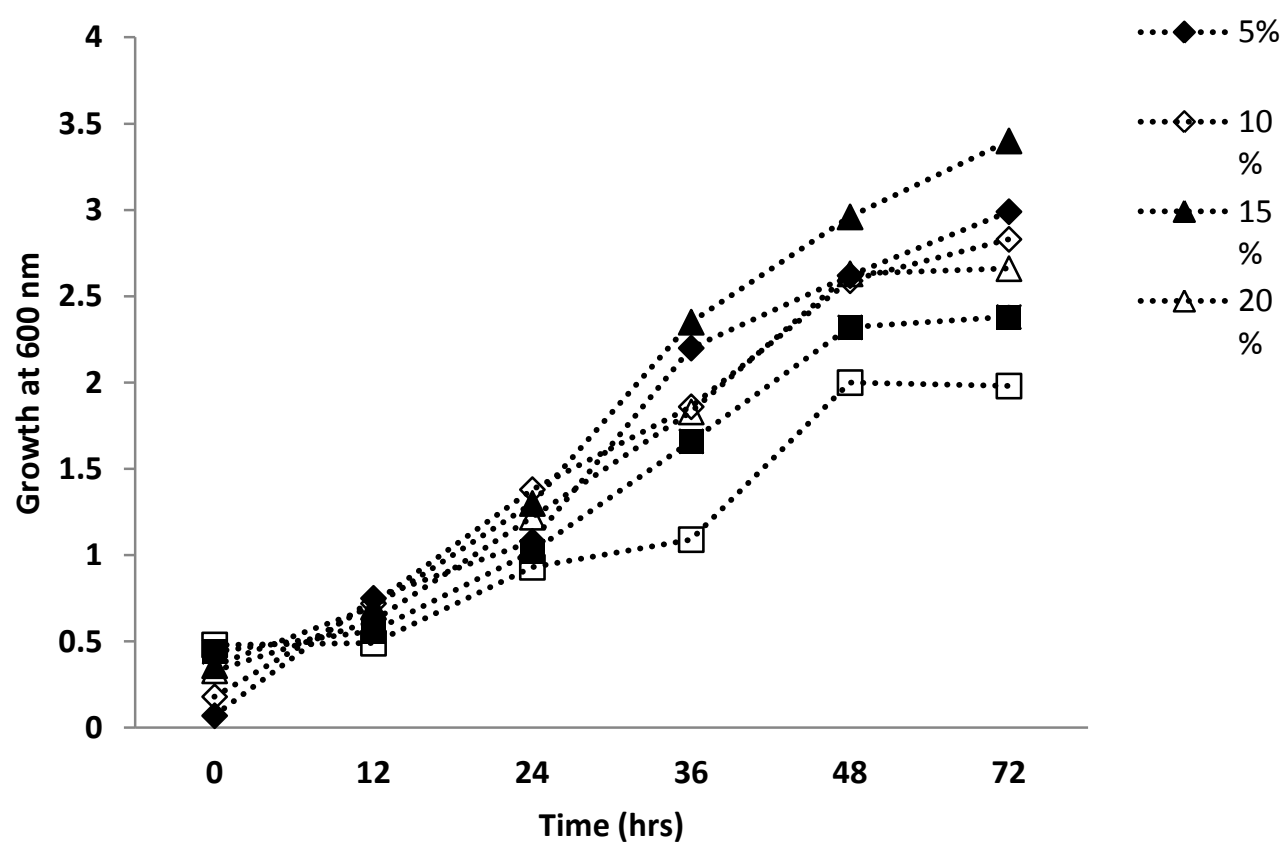

Figure 3:- Effect of increasing sugar concentration on growth of $S$. cerevisiae $\mathrm{KD} 2$ at $\mathrm{pH} 5$ and $35^{\circ} \mathrm{C}$ temperature. 


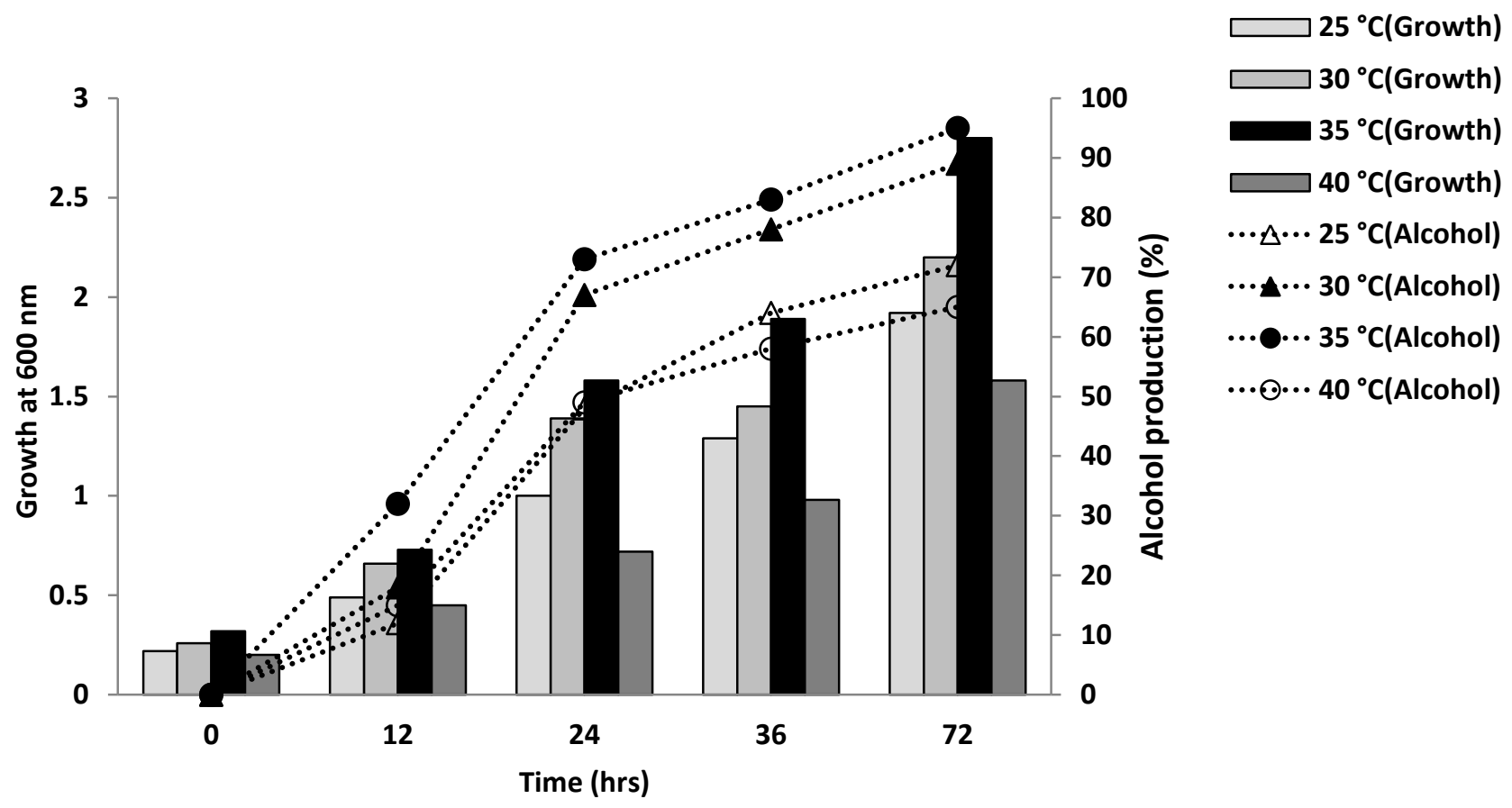

Figure 4:- Effect of temperature on ethanol production by S. cerevisiae KD2 at pH 5 and 15\% sugar concentration.

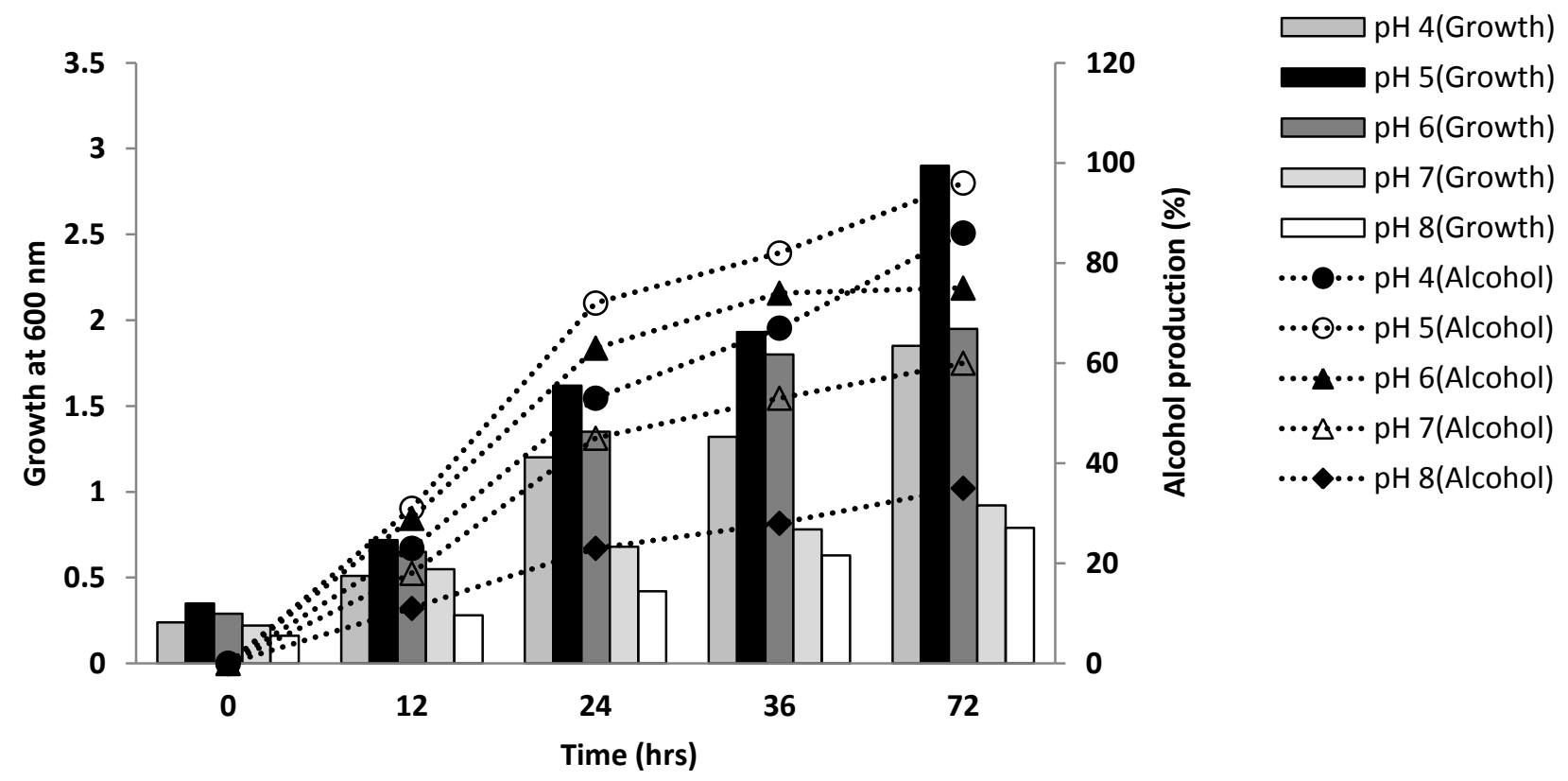

Figure 5:- Effect of $\mathrm{pH}$ on ethanol production by S. cerevisiae $\mathrm{KD} 2$ at $15 \%$ sugar concentration and $35{ }^{\circ} \mathrm{C}$ temperature. 


\section{References:-}

1. Kamm B., Kamm M., Gruber P.R. and Kromus S. (2006). Biorefinery systems. An overview. In: Kamm B., Gruber P.R. \& Kamm M., eds. Biorefineries. Industrial processes and products. Statu quo and future directions. Vol.1. Weinheim, Germany: Wiley-VCH Verlag GmbH \& Co., 3-40.

2. Kamm B. and Kamm M. (2007a). The concept of biorefinery. Production of platform chemicals and final products. Chem. Ing. Tech. 79, 592-603.

3. Kamm B. and Kamm M. (2007b). International biorefinery systems. Pure Appl. Chem. 79, 1983-1997.

4. Demirbas A. (2009). Biorefineries: current activities and future developments. Energy Convers. Manage., 50, 2782-2801.

5. Cherubini F. (2010). The biorefinery concept: using biomass instead of oil for producing energy and chemicals. Energy Convers. Manage., 51, 1412-1421.

6. Briens C., Piskorz J. and Berruti F. (2008). Biomass valorization for fuel and chemicals production. A review. Int. J. Chem. Reactor Eng. 6,

7. Kamm B. and Kamm M. (2004a). Principles of biorefineries. Appl. Microbiol. Biotechnol. 64, 137-145.

8. Kamm B.and Kamm M. (2004b). Biorefinery. Systems. Chem. Biochem. Eng. Q. 18, 1-6.

9. Mandl M.G. (2010). Status of green biorefining in Europe. Biofuels, Bioprod. Biorefin. 4, $268-274$.

10. Koutinas A., Wang R., Campbell G.M. and Webb C. (2006). A whole crop biorefinery system: a closed system for the manufacture of non-food products. In: Kamm B., Gruber P.R. \& Kamm M., eds. Biorefineries. Industrial processes and products. Statu quo and future directions. Vol. 1. Weinheim, Germany: Wiley-VCH Verlag GmbH \& Co., 165-192.

11. Demirbas A. (2010a). Biorefinery. In: Biorefineries: for biomass upgrading facilities. London: Springer Verlag, 75-92.

12. Demirbas A. (2010b). Biorefinery technologies for biomass upgrading. Energy Sources Part A, 32, 1547-1558.

13. Carvalheiro F., Duarte L.C. and Girio F.M. (2008). Hemicellulose biorefineries: a review on biomass pretreatments. J. Sci. Ind. Res., 67, 849-864.

14. Cheng S.M. and Zhu S.D. (2009). Lignocellulosic feedstock biorefinery. The future of the chemical and energy industry. Bioresources, 4, 456-457.

15. Luo L., van der Voet E.and Huppes G. (2010). Biorefining of lignocellulosic feedstock. Technical, economic and environmental considerations. Bioresour. Technol. 101, 5023-5032.

16. Zhang Y.H.P. (2008). Reviving the carbohydrate economy via multi-product lignocellulose biorefinerie. J. Ind. Microbiol. Biotechnol. 35, 367-375.

17. Kumar M.N.S., Mohanty A.K., Erickson L. and Misra M. (2009a). Lignin and its applications with polymers. J. Biobased Mater. Bioenergy, 3, 1-24.

18. Chandrasekaran, M. and Bahkali, A H. (2013). Valorization of date palm (Phoenix dactylifera) fruit processing by-products and wastes using bioprocess technology-Review. Saudi Journal of Biological Sciences. 20, 105-120

19. Barreveld, W. H. (1993). Dates palm products, FAO agricultural services, bulletin No.101.

20. Cassman, K.G. and A.J. Liska. (2007). Food and fuel for all: Realistic or foolish?. Biofuel. Bioprod. Biorefin., $1,18-23$.

21. Saha, B.C. (2004). Lignocellulose Biodegradation and Applications in Biotechnology. In: Lignocellulose Biodegradation, Saha, B.C. and K. Hayashi (Eds.). American Chemical Society, Washington, DC., pp: 2-34.

22. Sharma, S., Sharma, V., Kuila, A. (2016). Cellulase production using natural medium and its application on enzymatic hydrolysis of thermo chemically pretreated biomass. 3 Biotech. 6, 139-143.

23. Gupte A, Madamwar D. (1997). Production of cellulolytic enzymes by coculturing of Aspergillus eilipticusand Aspergillus fumigatus grown on bagasse under solid state fermentation. Appl Biochem Biotechnol. 62, 267-274.

24. Mandel, M. and J. Weber (1969). Exoglucanase activity by microorganisms. Adv. Chem. 95, 391-414.

25. Brandberg, T. (2005). Fermentation of undetoxified dilute acid lignocellulose hydrolyzate for fuel ethanol production, Chemical Reaction Engineering, Chalmers University of Technology, Göteborg, Sweden,

26. Maiorella, B. L. (1985). Ethanol, In: Comprehensive Biotechnology, Moo-Young, M. (Ed.), First ed., Oxford: Pergamon Press Ltd.,

27. Demayer, A., Jacob, F., Jay, M., Menguy, G. and Perrier, J. (1982). La Bioconversion Bioénergétique, Ed. Tech. \& Doc., Lavoisier.

28. Sandesh B., Harinikumar K.M., Ravi K S. and Aditi P. (2014). Optimization of Bioethanol Production from Fruit Wastes using Isolated Microbial Strains. International Journal of Advanced Biotechnology and Research. 5,598-604 
29. Miller, Gail Lorenz. (1959). Use of dinitrosalicylic acid reagent for determination of reducing sugar. Analytical chemistry. 31, 426-428.

30. Arthur, C., Ueda M., and Brown T. (1968), Spectrophotometric determination of ethanol in wine." American Journal of Enology and Viticulture 19, 160-165.

31. Goerging HD, Van Soest JP (1975). Agri Res Ser. US Department of Agriculture; Washington, D.C:. Forage fibre analysis.

32. Reda M. El-Shishtawy, S. A. Mohamed, A. M. Asiri, Abu-bakr M. Gomaa, I. H. Ibrahim and Hasan, A. A.T. (2015). Saccharification and hydrolytic enzyme production of alkali pre-treated wheat bran by Trichoderma virens under solid state fermentation. BMC Biotechnology.15,37-42.

33. Marcelle A, Betty-Jayne de Vos, Visser MS. (2007). The preparation, assay and certification of aqueous ethanol reference solutions. Accred Qual Assur. 12, 188-193.

34. Bradford MM. (1976) A rapid sensitive method of quantitation micro gram quantities of proteins utilizing the principles of protein-dye binding. Anal Biochem. 72,248-54.

35. Ruhul Amin M., Saquib Hossain M., Sarker M. (2013). Simulation of Ethanol Production by Fermentation of Molasses, Journal of Engineering. 4, 69-73.

36. Alemayehu, G. (2014). Bioethanol Production from Fruit Wastes and Factors Affecting Its Fabrication. I. J. of Chem. and Nat. Sc. 5, 132-140.

37. Chen Y, Stevens MA, Zhu Y, Holmes J, Xu H (2013) Understanding of alkaline pretreatment parameters for corn stover enzymatic saccharification. Biotechnol Biofuel 6:1-10.

38. Perez, J., J. Munoz-Dorado, T. de la Rubia and J. Martinez. (2002 \}. Biodegradation and biological treatments of cellulose, hemicellulose and lignin: An overview. Int. Microbiol. 5, 53-63.

39. Hong, L.S., Ibrahim, D. and Omar, I.C. (2011). Lignocellulolytic Materials-as a Raw Material for the Production of Fermentable Sugars via Solid State Fermentation. Asian Journal of Scientific Research. 4, 53-61.

40. Leonel, M., Ortega, G.E., Andrea, K., Astoreca, L. and Alconada,T.M. (2013). Screening of Fusarium graminearum isolates for enzymes extracellular and deoxynivalenol production Journal of Mycology. 358, 140147.

41. Dayanandan, A., Madankumar, A. and Premalatha A. (2015). Enzymatic hydrolysis of alkali pretreated rice straw for the enhanced production of fermentable sugars. Journal of Chemical and Pharmaceutical Research.7, 591-597.

42. Hong, L.S., Ibrahim, D. and Omar, I.C. (2011). Lignocellulolytic Materials-as a Raw Material for the Production of Fermentable Sugars via Solid State Fermentation. Asian Journal of Scientific Research. 4, 53-61.

43. Saravanan, R., Darah, I. and Ibrahim, C.O. (2009). Optimization of physical parameter for the production of fermentable sugars using kenaf, Hibiscus cannabinus as substrate. Proceedings of the 2nd Collaborative Conference on Life Science: Synergy for Enhancement of Quality of Life, Feb. 10-11, Surabaya, Indonesia, pp: 153-153.

44. Teoh, C.S., Darah, I., Rashidah, A.R. and Ibrahim, C.O. (2008). Solid state fermentation of rice straw and rice husk for fermentable sugar production. Proceeding of the 6th IMT-GT UNINET Conference on Sustaining Natural Resources Towards Enhancing the Quality of Life within the IMT-GT Zone, Aug. 28-30, Penang, Malaysia, pp: 122-125.

45. De Souza, D.F., C.G.M. de Souza and R.M. Peralta, 2001. Effect of easily metabolizable sugars in the production of xylanase by Aspergillus tamarii in solid state fermentation. Process Biochem., 36, 835-838.

46. ([46]) Ensinas, A. V., Modesto, M., S. Nebra, A. and Serra, L. (2009). Reduction of irreversibility generation in sugar and ethanol production from sugarcane. Energy. 34, 680-688,

47. Yoon, L.W., Ngoh, G.C. Chua, A.S.M. (2012) Simultaneous production of cellulase and reducing sugar from alkali-pretreated sugarcane bagasse via solid state fermentation. BioResources. 7, 5319-5332.

48. Kosaric, N. and Velikonja, J. (1995). Liquid and gaseous fuels from biotechnology: challenge and opportunities," FEMS Microbiology Reviews, 16, 111-142.

49. Olsson, L. and Hahn-Hägerdal, B. (1993). "Fermentative performance of bacteria and yeasts in lignocellulose hydrolysates," Process Biochemistry. 28, 249-257.

50. Muhammad, I., Muhammad, N., and Quratualain, S. (2014). Ethanol production from agricultural wastes using Sacchromyces cervisae. Braz J Microbiol. 45, 457-465.

51. Md. Fakruddin, Md. Abdul Quayum, Monzur Morshed Ahmed and Naiyyum Choudhury Analysis of Key Factors Affecting Ethanol Production by Saccharomyces cerevisiae IFST-072011.

52. Gough, S., Flynn, O., Hack, D.J. and Marchant, R. (1996) Fermentation of molasses using a thermotolerant yeast, Klyuyveromyces marxianus IMB3: simplex optimization of media supplements. Appl Microbiol Biotechnol 46, 187-190. 
53. Pramanik, K. (2003). Parametric Studies on Batch Alcohol Fermentation Using Saccharomyces Yeast Extracted from Toddy. J. Chin. Institution Chemistry Engineers. 34, 487-492

54. Redzepovic, S., Orlic, S., Sikora, S., Majdak, A., Pretorius, I. S. (2002). Identification and characterization of Saccharomyces cerevisiaeand Saccharomyces paradoxusstrains isolated from Croatian vineyards, Whileyinterscience journals, pg. 350

55. Roehr, M. (2001). The Biotechnology of Ethanol: Classical and Future Applications. Chichester: Wiley-VCH. Pg. 232.

56. Yadav, A., N. Dilbaghi, and S. Sharma (1997). Pretreatment of sugarcane molasses for ethanol production by yeast, Indian Journal of Microbiology, 37, 37-40.

57. Yah, C.S., S.E. Iyuke, E.I. Unuabonah, O. Pillay, C. Vishanta and S.M. Tessa. (2010). Temperature optimization for bioethanol production from corn cobs using mixed yeast strains. Journal Biology.Science., 10,103-108. 